Jurnal Ilmu Ilmu Agribisnis: Journal of Agribusiness Science, 9(4), Agustus 2021

\title{
PENGARUH KETERAMPILAN, PENGALAMAN KERJA DAN GAYA KEPEMIMPINAN \\ MANDOR TERHADAP PRODUKTIVITAS TENAGA KERJA PEMANEN NANAS (PT GREAT GIANT PINEAPPLE DEPARTEMEN PLANTATION GROUP 4)
}

\author{
(Work Experience, Ability And Leadership Style influenced Towards Labor Productivity Of Pineapple \\ (PT Great GiantPineapple Department Plantation Group 4 )
}

Wayan Astika Darmayanti, Wuryaningsih Dwi Sayekti, Raden Hanung Ismono

Jurusan Agribisnis, Fakultas Pertanian Universitas Lampung, Jl. Prof. Dr. Soemantri Brojonegoro No.1

Bandar Lampung 35141, email: wuryaningsih.dwisayekti@fp.unila.ac.id

\begin{abstract}
The aims of this research were to study the level of nutritional status, work skills, work experience, and foreman leadership style as well as its effect on the productivity of pineapple harvesting labor in PT Great Giant Pineapple Department Plantation Group 4. The research is conducted by surrvey method at PT Great Giant Pineapple Department Plantation Group 4,Labuhan Ratu Sudistrict, East Lampung Regency. Data is collected in August-September 2019. The total respondent for this research are 50 workers are chosen by purposive method. Analyzed by quantitative descriptive and multiple linear regression. The result of this research showed the level nutrition status of labor was normal with good work skills, work experience of less than a year, the leadership style applied was democratic and level of labor productivity was moderate. The laor productivity was influenced by skills, work experience, foreman leadership style, age and education.
\end{abstract}

Keywords : experience, foreman, nutritional status, productivity, skills.

Received: 23 June $2020 \quad$ Revised: 12 August 2020

\section{PENDAHULUAN}

Berdasarkan Badan Pusat Statistik (2018) Pertumbuhan Produk Domestik Bruto (PDB) Indonesia pada lapangan usaha seperti industri pengolahan, konstruksi, perdangangan, pertanian, dan lain-lain dari tahun 2015-2017 tergolong fluktuatif, namun pada tahun 2017 sektor pertanian adalah sektor dengan persentase terendah, yaitu 0,49 persen. Rendahnya PDB pertanian menggambarkan bahwa produktivitas pertanian perlu ditingkatkan sehingga mampu berkontribusi lebih maksimal dalam perekonomian nasional.

Menurut Direktorat Jendral Perkebunan (2013) komoditas perkebunan merupakan salah satu andalan dari sektor pertanian sebagai pendapatan nasional dan devisa negara, di Provinsi Lampung terdapat perkebunan rakyat, perkebunan swasta dan perkebunan milik pemerintah. Salah satu perkebunan swasta yang terbesar adalah PT Great Giant Pineapple.

PT Great Giant Pineapple memiliki empat departemen Plantation Group (PG). Departemen Plantation Group 4 (PG 4) merupakan hasil dari akuisisi PT Great Giant Pineapple dan PT
Accepted:27 August 2020

DOI: http://dx.doi.org/10.23960/jiia.v9i4.5406

Nusantara Tropical Farm yang baru diresmikan pada awal tahun 2018. Terdapat beberapa penyesuaian yang dilakukan, salah satu penyesuaian yang dilakukan adalah peralihan lahan yang semula mayoritas digunakan untuk budidaya pisang, saat ini sebagian besar dialihkan untuk budidaya nanas yaitu 1.573 ha. Peralihan lahan tersebut berdampak pada mutasi tenaga kerja untuk memenuhi kebutuhan tenaga kerja pada departemen nanas.

Menurut Kepala bagian pemanenan nanas, mutasi tenaga kerja berpengaruh terhadap kemampuan dalam melakukan pekerjaan. Produktivitas tenaga kerja pemanenan nanas dikatakan masih rendah. Menurut Busro (2018) produktivitas menggambarkan hubungan antara tingkat keefektifan yang dicapai dengan tingkat keefisienan dengan menggunakan sumber daya yang tersedia. Rata-rata setiap tenaga kerja memanen 200-300 buah nanas, jumlah tersebut masih kurang dari standar yakni 450 buah per hari. Kesalahan yang sering dilakukan oleh tenaga kerja adalah memanen buah dengan ukuran atau tingkat kematangan yang kurang tepat. Penelitian Ukkas (2017), menunjukan bahwa pengalaman kerja berpengaruh terhadap produktivitas tenaga kerja. 
Menurut penelitian Mazdayani, Sayekti, dan Nugraha (2014) keterampilan kerja merupakan salah satu faktor yang memengaruhi kinerja yang berpengaruh terhadap produktivitas. Menurut hasil penelitian Simamora, Sayekti, dan Situmorang (2016), salah satu faktor yang memengaruhi produktivitas adalah status gizi. Selain itu gaya kepemimpinan mandor juga berpengaruh terhadap kinerja tenaga kerja (Alimah, Sayekti dan Soelaiman. 2016).

Berdasarkan uraian pedahuluan maka perlu dilakukan penelitian mengenai beberapa faktor yang memengaruhi produktivitas tenaga kerja pemanenan nanas untuk mengetahui upaya yang tepat yang dapat dilakukan perusahaan dalam meningkatkan produktivitas tenaga kerja. Tujuan dilakukannya penelitian ini adalah untuk mempelajari tingkat status gizi, keterampilan, pengalaman, persepsi gaya kepemimpinan mandor dan pengaruhnya terhadap produktivitas tenaga kerja pemanen nanas.

\section{METODE PENELITIAN}

Metode yang digunakan dalam penelitian ini adalah metode survai di PT Great Giant Pineapple departemen PG 4 di Kecamatan Labuhan Ratu, Kabupaten Lampung Timur. Waktu pengumpulan data penelitian dilakukan pada bulan AgustusSeptember 2019. Jumlah sampel ditentukan menggunakan rumus yang merujuk pada teori Sugiarto et al. (2003). Sampel yang digunakan dalam penelitian ini berjumlah 50 orang. Pengambilan sampel dilakukan secara purposive dengan ketentuan sampel pada setiap mandor memiliki keterampilan yang beragam, sehingga penelitian ini dapat menyajikan hasil yang maksimal.

Data yang digunakan adalah data primer meliputi data tenaga kerja pemanenan nanas di PT Great Giant Pineapple departemen PG 4, antara lain data identitas tenaga kerja, berat dan tinggi badan, pengalaman keja, persepsi terhadap gaya kepemimpinan mandor, tingkat keterampilan kerja, jumlah buah yang dipanen tenaga kerja yang diperoleh melalui teknik wawancara dengan mengunakkan kuesioner (daftar pertanyaan) yang telah dipersiapkan dan data sekunder meliputi luas PT Great Giant Pineapple departemen PG 4, jumlah tenaga kerja, jumlah mandor, dan lain-lain.

Data gaya kepemimpinan mandor merupakan data yang diperoleh berdasarkan persepsi tenaga kerja terhadap mandor sehingga memerlukan uji validitas dan uji reliabilitas.
Uji validitas digunakan untuk mengetahui apakah setiap butir pertanyaan dapat mengasilkan data yang sesuai. Butir pertanyaan dikatakan valid jika nilai $r$ hitung $>r$ tabel atau $p>0,05$. Berdasarkan uji validitas yang dilakukan dengan menggunakan SPSS versi 20 pertanyaan indikator pemberian tugas, pembuatan keputusan, kesempatan berpendapat, tingkat komunikasi, hubungan emosional, cara pengawasan, penanggungjawab, dan pecarian solusi pada variabel gaya kepemimpinan mandor adalah valid. Uji reliabilitas digunakan untuk mengukur sejauh mana alat ukur yang digunakan dapat dipercaya. Kuesioner dikatakan reliabel jika nilai alpha cronbach lebih dari 0,60. Berdasarkan uji reliabilitas dengan menggunakan SPSS versi 20 kuesioner persepsi gaya kepemimpinan mandor reliabel karena diperoleh nilai alpha cronbach sebesar 0,851 .

Data variabel keterampilan kerja dan gaya kepemimpinan mandor pada penelitian ini diperoleh dalam data berskala ordinal. Menurut Sarwono (2013) data ordinal sebenarnya adalah data kualitatif, karena dalam penggunaan analisis linier beganda, data yang diperoleh setidaknya merupakan data dengan skala interval. Prosedur statistik seperti regresi, korelasi pearson, uji t dan lain sebagainya mengharuskan data berskala interval. sehingga perlu diubah menjadi skala interval. Sebelum melakukan analisis data, Pada penelitian ini data berskala ordinal diubah menjadi interval dengan method of succesive interval (MSI).

Metode analisis data yang digunakan adalah analisis deskriptif kuantitatif dan analisis regresi linier berganda. Penelitian ini menggunakan analisis deskriptif kuantitaif untuk mengetahui tingkat status gizi, keterampilan, pengalaman, persepsi gaya kepemimpinan mandor dan produktivitas tenaga kerja. Persepsi gaya kepemimpinan mandor dianalisis dengan membuat garis kategorisasi. Garis kategori dibuat berdasarkan item pernyataan untuk menilai variabel dan juga jumlah sampel yang digunakan. Menurut Sugiyono 2013 rentang skor setiap kategori ditentukan sebagai berikut:

Rentang skor $=\frac{(\mathrm{JR} X \mathrm{JB} \times \mathrm{ST})-(\mathrm{JR} \times \mathrm{JB} \times \mathrm{SR})}{\mathrm{JK}}$

Keterangan :

JR = Jumlah Responden

JB = Jumlah butir soal

ST $\quad=$ Skor tertinggi 
SR

$=$ Skor terendah

JK

$=$ Jumlah kategori

Gaya kepemimpianan mandor dinilai berdasarkan persepsi tenaga kerja terhadap mandor yang dikategorikan menjadi tiga yaitu bebas, otoriter dan demokratis. Analisis regresi linier berganda digunakan untuk mengetahui pengaruh status gizi $\left(\mathrm{X}_{1}\right)$, keterampilan kerja $\left(\mathrm{X}_{2}\right)$, pengalaman kerja $\left(\mathrm{X}_{3}\right)$, dan gaya kepemimpinan mandor $\left(\mathrm{X}_{4}\right)$ serta identitas individu yang melekat pada diri tenaga kerja seperti usia $\left(\mathrm{X}_{5}\right)$, pendidikan $\left(\mathrm{X}_{6}\right)$ dan jenis kelamin (D) terhadap produktivitas tenaga kerja pemanenan nanas (Y). Model regresi yang digunakan adalah (Sugiyono, 2013)

$$
\begin{aligned}
\mathrm{Y}= & \mathrm{bo}+\mathrm{b}_{1} \mathrm{X}_{1}+\mathrm{b}_{2} \mathrm{X}_{2}+\mathrm{b}_{3} \mathrm{X}_{3}+\mathrm{b}_{4} \mathrm{X}_{4}+\mathrm{b}_{4} \mathrm{X}_{4}+\mathrm{b}_{5} \mathrm{X}_{5} \\
& +\mathrm{b}_{6} \mathrm{X}_{6}+\mathrm{D}+\mathrm{e}
\end{aligned}
$$

Keterangan:

$\begin{array}{ll}\mathrm{Y} & \begin{array}{l}\text { = Produktivitas tenaga kerja pemanenan } \\ \text { (unit/hari) }\end{array} \\ b o & =\text { Intersep } \\ b i & =\text { Koefisien regresi }(\mathrm{i}=1,2,3, \ldots . . \mathrm{n}) \\ \mathrm{X}_{1} & =\text { Status gizi }\left(\mathrm{Kg} / \mathrm{m}^{2}\right) \\ \mathrm{X}_{2} & =\text { Keterampilan kerja }(\text { likert }) \\ \mathrm{X}_{3} & =\text { Pengalaman kerja }(\text { thn }) \\ \mathrm{X}_{4} & =\text { Persepsi gaya kepemimpinan (likert) } \\ \mathrm{X}_{5} & =\text { Usia (thn) } \\ \mathrm{X}_{6} & =\text { Pendidikan }(\text { likert }) \\ \mathrm{D} & =\text { Laki-laki }(1) \\ & \text { Perempuan }(0) \\ \mathrm{e} & =\text { Standart error }\end{array}$

Pengujian parameter regresi, dilakukan pengujian koefisien determinasi $\left(\mathrm{R}^{2}\right)$ yang bertujuan untuk mengetahui seberapa besar kemampuan variabel bebas (status gizi, keterampilan kerja, pengalaman kerja, gaya kepemimpinan mandor, usia, pendidikan, dan jenis kelamin) terhadap variabel terikat (produktivitas tenaga kerja pemanenan nanas). Selain itu dilakukan pula pengujian secara serentak (Uji F) dan secara parsial (Uji t). Pengujian dapat dilihat dengan membandingkan angka taraf signifikansi $0,1(10 \%)$.

\section{HASIL DAN PEMBAHASAN}

\section{Karakteristik Responden}

Karakteristik responden adalah sifat yang melekat pada diri responden dan tidak terpisahkan yang akan berpengaruh terhadap kegiatan yang dilakukan. Karakteristik responden dalam penelitian ini dilihat dari usia, pendidikan dan jenis kelamin. Tenaga kerja pemanenan nanas PT Great Giant Pineapple departemen PG 4 seluruhnya berada pada usia dewasa yaitu 19-60 tahun. Menurut Badan Pusat Statistik (2020) batas umur minimal tenaga kerja adalah 15 tahun dan maksimal 64 tahun, sehingga seluruh tenaga kerja pemanenan nanas berada pada usia produktif.

Sebagian besar pendidikan tenaga kerja adalah lulus sekolah menengah atas (SMA) yaitu sebanyak 16 orang atau sebesar 32 persen dan sebesar 54 persen perempuan yaitu 27 orang. Sebagian besar pendidikan tenaga kerja perempuan hanya lulus sekolah dasar (SD) sedangkan laki-laki lulus SMA. PT Great Giant Pineapple departemen PG 4 tidak melakukan spesifikasi jenis kelamin untuk melakukan pekerjaan pemanenan nanas karena tidak membutuhkan kekuatan khusus.

\section{Status Gizi}

Variabel status gizi dinilai dengan Indeks Masa Tubuh (IMT) yang diperoleh dari perhitungan berat badan $(\mathrm{Kg})$ dibagi dan tinggi badan $\left(\mathrm{m}^{2}\right)$. Distribusi nilai IMT tenaga kerja pemanenan nanas disajikan pada Tabel 1, dimana dapat dilihat bahwa tenaga kerja pemanenan nanas di PT Great Giant Pineapple departemen PG 4 sebagian besar berada dalam kategori berat badan normal yaitu 26 orang (52). Artinya tenaga kerja memiliki perbandingan tinggi dan berat badan yang baik serta tidak termasuk gizi berlebih atau kekurangan gizi. Persentase tenaga kerja pemanenan nanas di PT Great Giant Pineapple departemen PG 4 yang berada pada kategori gizi kurang (4\%) lebih rendah dibandingkan dengan tenaga kerja dengan kategori gizi lebih (16\%). Terdapat tenaga kerja yang berisiko obesitas tergolong besar yaitu 28 persen.

Tabel 1. Distribusi nilai IMT tenaga kerja pemanenan nanas di PT Great Giant Pineapple departemen PG 4

\begin{tabular}{llcc}
\hline $\begin{array}{c}\text { IMT } \\
\left(\mathrm{kg} / \mathrm{m}^{2}\right)\end{array}$ & Kategori & $\begin{array}{c}\text { Jumlah } \\
\text { Responden } \\
(\text { orang) }\end{array}$ & $\begin{array}{c}\text { Persentase } \\
(\%)\end{array}$ \\
\hline$<18,5$ & Gizi kurang & 2 & 4 \\
$18,5-22,9$ & Gizi normal & 26 & 52 \\
$23,0-24,9$ & $\begin{array}{l}\text { Gizi } \\
\text { berlebih }\end{array}$ & 8 & 16 \\
$25,0-29,9$ & $\begin{array}{l}\text { Berisiko } \\
\text { obesitas }\end{array}$ & 14 & 28 \\
$>30,0$ & Obesitas & 0 & 0 \\
\hline Total & & 50 & 100 \\
\hline
\end{tabular}




\section{Keterampilan dan Pengalaman Kerja}

Keterampilan kerja dinilai dengan menggunakan indikator kesesuaian tingkat kematangan dan ukuran buah yang dipanen dengan standar kualitas. Kematangan buah dilihat dari warna kulit dan daging buah, sedangkan ukuran buah diukur berdasarkan berat buah.

Keterampilan kerja dikategorikan manjadi tiga yaitu kategori rendah dinilai dengan skor satu apabila tenaga kerja memanen buah yang tidak sesuai dengan permintaan berdasarkan indikator kematangan dan ukuran buah. Kategori sedang dinilai dengan skor dua apabila tenaga kerja memanen buah yang hanya memenuhi salah satu indikator yaitu kematangan atau ukuran buah. Kategori tinggi dinilai dengan skor tiga apabila tenaga kerja dapat memanen buah yang sesuai dengan permintaan berdasarkan indikator kematangan dan ukuran buah.

Pengalaman kerja dalam penelitian ini dinilai berdasarkan masa kerja di bagian pemanenan nanas PT Great Giant Pineapple departemen PG 4. Usia dapat memengaruhi kemampuan tenaga kerja sehingga dapat memengaruhi keterampilan kerja. Distribusi usia, keterampilan dan pengalaman tenaga kerja pemanenan nanas di PT Great Giant Pineapple departemen PG 4 dapat dilihat pada Tabel 2.

Berdasarkan Tabel 2 diketahui bahwa peningkatan pengalaman kerja sejalan dengan peningkatan keterampilan kerja, sebagian besar tenaga kerja pemanenan nanas memiliki keterampilan tinggi yaitu sebanyak 30 orang dengan mayoritas berusia 30-40 tahun sebanyak 15 orang dan sebanyak 9 orang memiliki pengalaman kerja selama 2-2,9 tahun, namun tenaga kerja yang memiliki keterampilan kerja tinggi dengan pengalaman kerja 3-4 tahun tergolong sedikit yaitu enam orang dan mayoritas berusia 30-40 tahun. Tenaga kerja yang memiliki tingkat keterampilan sedang sebanyak 17 orang, sebagian besar berusia 19-29 tahun dengan pengalaman kerja selama 0-1,9 tahun.

PT Great Giant Pineapple departemen PG4 perlu meningkatkan keterampilan tenaga kerja pemanenan nanas dengan cara memberikan pelatihan dan pendampingan yang lebih intensif sehingga tenaga kerja akan semakin cepat memahami kriteria buah yang harus dipanen, sehingga dapat memanenen buah dengan tepat dan meningkatkan produktivitasnya.

Keterampilan tenaga kerja juga dapat ditingkatkan dengan penentuan kriteria usia maksimal 29 tahun pada saat penerimaan tenaga kerja baru, agar tenaga kerja dapat memiliki pengalaman kerja yang lebih lama sehingga produktivitas dapat meningkat. Menurut Sulistiyani dan Rosidah (2009) keterampilan kerja merupakan salah satu faktor yang memengaruhi produktivitas tenaga kerja, karena semakin baik tingkat keterampilan tenaga kerja maka dapat melakukan pekerjaan dengan produktif.

Tabel 2. Distribusi keterampilan dan pengalaman tenaga kerja pemanenan nanas di PT Great Giant Pineapple departemen PG 4

\begin{tabular}{|c|c|c|c|c|c|c|}
\hline \multirow{2}{*}{ Keterampilan Kerja } & \multirow{2}{*}{$\begin{array}{c}\text { Usia } \\
\text { (tahun) }\end{array}$} & \multicolumn{4}{|c|}{ Pengalaman Kerja (tahun) } & \multirow{2}{*}{ Total } \\
\hline & & $0-0,9$ & $1-1,9$ & $2-2,9$ & $3-4$ & \\
\hline \multirow{3}{*}{ Rendah } & $19-29$ & 1 & 0 & 0 & 0 & 1 \\
\hline & $30-40$ & 1 & 0 & 0 & 0 & 1 \\
\hline & $41-51$ & 1 & 0 & 0 & 0 & 1 \\
\hline \multicolumn{2}{|c|}{ Sub total } & 3 & 0 & 0 & 0 & 3 \\
\hline \multirow{3}{*}{ Sedang } & $19-29$ & 8 & 0 & 0 & 0 & 8 \\
\hline & $30-40$ & 6 & 1 & 0 & 0 & 7 \\
\hline & $41-51$ & 0 & 2 & 0 & 0 & 2 \\
\hline \multicolumn{2}{|c|}{ Sub total } & 14 & 3 & 0 & 0 & 17 \\
\hline \multirow{3}{*}{ Tinggi } & $19-29$ & 0 & 5 & 4 & 1 & 10 \\
\hline & $30-40$ & 0 & 3 & 9 & 3 & 15 \\
\hline & $41-51$ & 0 & 0 & 3 & 2 & 5 \\
\hline \multicolumn{2}{|c|}{ Sub total } & 0 & 8 & 16 & 6 & 30 \\
\hline \multicolumn{2}{|c|}{ Total } & 17 & 11 & 16 & 6 & 50 \\
\hline
\end{tabular}




\section{Gaya Kepemimpinan Mandor}

Gaya kepemimpinan mandor dinilai berdasarkan persepsi tenaga kerja terhadap mandor. Berdasarkan penelitian Alimah dkk (2016) gaya kepemimpinan demokratis diasumsikan sebagai gaya kepemimpinan yang sesuai untuk pekerjaan lapangan maka dalam penelitian ini skor tertinggi mengarah pada karakteristik gaya kepemimpinan demokratis. Gaya kepemimpinan mandor dinilai dengan menggunakan skor (1) "bebas", (2) "otoriter", (3) "demokratis" dan diukur menggunakan empat dimensi yaitu kekuasaan mandor, komunikasi, pengawasan, dan tanggung jawab. Secara keseluruhan distribusi jawaban tenaga kerja terhadap gaya kepemimpinan mandor tenaga kerja pemanenan nanas di PT Great Giant Pineapple departemen PG 4 dapat dilihat pada Tabel 3 dan Gambar 1.

Dimensi kekuasaan mandor menjelaskan bagaimana sikap kepemimpinan mandor panen terhadap tenaga kerja dalam menjalankan tugas dan membuat keputusan. Berdasarkan Tabel 3 sebagian besar memberikan jawaban dengan skor 3 sejumlah 56 sehingga gaya kepemimpinan mandor pemanenan nanas berdasarkan dimensi kekuasaan mandor adalah demokratis. Dimensi komunikasi menjelaskan bagaimana komunikasi dan hubungan emosional yang terjalin antara mandor dan tenaga kerja. Sebagian besar tenaga kerja diberikan kesempatan untuk menyampaikan pendapat atau saran, hal tesebut sering terjadi ketika diskusi pembuatan keputusan atau kebijakan. Pada saat kegiatan kerja, komunikasi yang lebih sering terjadi adalah tingkat komunikasi satu arah dari mandor kepada tenaga kerja sebagai bentuk pengarahan atau perintah.

Tabel 3. Distribusi jawaban tenaga kerja terhadap gaya kepemimpinan mandor tenaga kerja pemanenan nanas di PT Great Giant Pineapple departemen PG 4.

\begin{tabular}{|c|c|c|c|c|c|}
\hline \multirow{2}{*}{ Dimensi } & \multirow{2}{*}{$\begin{array}{l}\text { Perta- } \\
\text { nyaan }\end{array}$} & \multicolumn{3}{|c|}{$\begin{array}{c}\text { Jawaban tenaga } \\
\text { kerja }\end{array}$} & \multirow{2}{*}{$\begin{array}{c}\text { Jumlah } \\
\text { skor }\end{array}$} \\
\hline & & 1 & 2 & 3 & \\
\hline $\begin{array}{l}\text { Kekuasaan } \\
\text { mandor }\end{array}$ & 2 & 4 & 40 & 56 & 252 \\
\hline Komunikasi & 3 & 19 & 55 & 76 & 357 \\
\hline Pengawasan & 1 & 0 & 36 & 14 & 114 \\
\hline $\begin{array}{l}\text { Tanggung } \\
\text { jawab }\end{array}$ & 2 & 0 & 47 & 53 & 253 \\
\hline Total & 8 & 23 & 178 & 199 & 976 \\
\hline
\end{tabular}

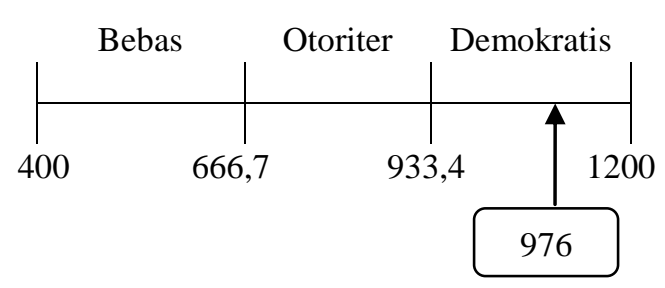

Gambar 1. Garis kategori gaya kepemimpinan mandor pemanenan nanas di PT Great Giant Pineapple departemen PG 4

Kedekatan emosional antara mandor dan tenaga kerja bersifat subjektif sehingga terdapat tenaga kerja yang tidak terlalu dekat dengan mandor namun ada pula yang sudah dekat seperti teman biasa. Pada Tabel 3 dapat dilihat bahwa mayoritas tenaga kerja memberikan jawaban dengan skor 3 sejumlah 76 sehingga gaya kepemimpinan mandor pemanenan nanas di PT Great Giant Pineapple departemen PG 4 berdasarkan dimensi komunikasi adalah demokratis.

Dimensi pengawasan menjelaskan cara pengawasan yang dilakukan oleh mandor terhadap pekerjaan yang dilakukan tenaga kerja dan hasil panen, sebagian besar tenaga kerja memiliki persepsi bahwa mandor melakukan pengawasan secara ketat, hal tersebut bertujuan agar tenaga kerja lebih disiplin dalam melakukan pekerjaan. Pada tabel 3 dapat dilihat bahwa jumlah skor tertinggi adalah 36 pada jawaban skor 2 maka gaya kepemimpinan mandor pemanenan nanas berdasarkan dimensi pegawasan adalah otoriter.

Dimensi tanggungjawab menjelaskan mengenai siapa yang bertanggungjawab atas keberhasilan dan proses kegiatan kerja, serta bagaimana cara menemukan solusi ketika menghadapi permasalahan di lingkungan pekerjaan. Bertangungjawab atas keberhasilan dan kegiatan kerja adalah mador namun ketika meghadapi masalah pencarian solusi dilakukan bersama-sama mandor dan tenaga kerja, karena tenaga kerja memiliki kesempatan untuk menyampaikan pendapat namun keputusan akhir adalah tanggung jawab mandor. Berdasarkan Tabel 3 jawaban tenaga kerja sebagaian besar adalah pada skor 3 sejumlah 53, maka gaya kepemimpinan mandor pemanenan berdasarkan dimensi tanggung jawab adalah demokratis. Pada Gambar 1 dapat dilihat bahwa mandor pemanenan nanas di PT Great Giant Pineapple departemen PG 4 memiliki gaya kepemimpinan demokratis. Hasil penelitian ini sesuai dengan teori Sutarto (2006) bahwa wewenang pemimpin tidak mutlak, keputusan dan 
kebijakan dibuat bersama-sama antara pimpinan dan bawahan, pimpinan juga harus melakukan pengawasan dengan baik serta bertanggung jawab terhadap keberhasilan kelompok atau organisasi.

\section{Produktivitas tenaga kerja}

Produktivitas tenaga kerja pemamenan nanas diukur berdasarkan jumlah buah yang dipanen oleh tenaga kerja per hari. Kebijakan upah yang diterima juga berdasarkan jumlah buah yang dipanen, setiap buah yang mampu dipanen tenaga kerja dihargai sebesar Rp217,00 per buah, sehingga semakin banyak buah yang dipanen atau semakin tinggi tingkat produktivitas tenaga kerja maka semakin meningkat pula upah yang akan diterima. Distribusi jumlah nanas yang dipanen tenaga kerja pemanenan dapat dilihat pada Tabel 4.

Pada Tabel 4 dapat dilihat bahwa sebagian besar tenaga kerja mampu memanen buah nanas 301-400 buah per hari, yaitu 46 persen, produktivitas tenaga kerja pemanenan nanas termasuk dalam kategori sedang. Jumlah tenaga kerja dengan tingkat produktivitas sangat rendah juga tergolong besar yaitu 32 persen atau sebanyak 16 orang, sehingga perusahaan perlu meningkatkan produktivitas tenaga kerja. Terdapat dua tenaga kerja yang memiliki produktivitas tinggi. Kedua tenaga kerja tersebut memiliki keterampilan yang baik dengan pengalaman kerja 4 tahun dan dalam kondisi gizi yang baik sehingga pengalaman kerja merupakan salah satu faktor yang dapat memengaruhi tingkat produktivitas tenaga kerja, selain itu menjaga tenaga kerja berada pada kondisi berat badan normal juga diperlukan.

Tabel 4. Distribusi jumlah buah yang dipanen tenaga kerja pemanenan nanas di $P T$ Great Giant Pineapple departemen PG 4

\begin{tabular}{lccc}
\hline Kategori & $\begin{array}{c}\text { Jumlah } \\
\text { Nanas } \\
\text { (buah) }\end{array}$ & $\begin{array}{c}\text { Jumlah } \\
\text { Tenaga } \\
\text { Kerja } \\
\text { (orang) }\end{array}$ & $\begin{array}{c}\text { Persentase } \\
(\%)\end{array}$ \\
\hline $\begin{array}{l}\text { Sangat } \\
\text { Rendah } \\
\text { Rendah }\end{array}$ & $100-200$ & 16 & 32 \\
Sedang & $201-300$ & 9 & 18 \\
Tinggi & $301-400$ & 23 & 46 \\
$\begin{array}{l}\text { Sangat } \\
\text { tinggi }\end{array}$ & $401-500$ & 2 & 4 \\
\hline
\end{tabular}

Faktor-faktor yang Memengaruhi Produktivitas Tenaga Kerja Pemanenan Nanas di PT Great Giant Pineapple Departemen PG 4

Pengaruh status gizi $\left(\mathrm{X}_{1}\right)$, keterampilan kerja $\left(\mathrm{X}_{2}\right)$, pengalaman kerja $\left(X_{3}\right)$, gaya kepemimpinan $\left(X_{4}\right)$, usia $\left(\mathrm{X}_{5}\right)$, pendidikan $\left(\mathrm{X}_{6}\right)$ dan jenis kelamin (D) terhadap produktivitas tenaga kerja pemanenan nanas (Y) dilakukan dengan menggunakan analisis regresi linear berganda lalu dianalisis berdasarkan uji koefisien determinasi $\left(\mathrm{R}^{2}\right)$, uji $\mathrm{F}$ (serentak), dan uji t (parsial).

Uji $\mathrm{R}^{2}$ atau koefisien determinasi untuk mengetahui seberapa besar variabel bebas, yaitu status gizi $\left(\mathrm{X}_{1}\right)$, keterampilan kerja $\left(\mathrm{X}_{2}\right)$, pengalaman kerja $\left(\mathrm{X}_{3}\right)$, gaya kepemimpinan $\left(\mathrm{X}_{4}\right)$, usia $\left(\mathrm{X}_{5}\right)$, pendidikan $\left(\mathrm{X}_{6}\right)$ dan jenis kelamin (D) dapat menjelaskan variabel terikat (produktivitas tenaga kerja pemanenan nanas $(\mathrm{Y})$. Nilai koefisien determinasi $\left(R^{2}\right)$ pada penelitian ini 0,923 yang berarti 92,3 persen produktivitas tenaga kerja pemanenan nanas dapat dijelaskan oleh variabel bebas dalam model, sedangkan 7,70 persen dijelaskan oleh variabel lain yang tidak dimasukan kedalam model.

Uji $F$ atau uji serentak pada penelitian ini digunakan untuk mengetahui apakah variabel bebas berpengaruh secara bersama-sama variabel terikat. Berdasarkan hasil regresi diperoleh nilai $\mathrm{F}$ hitung adalah 84,756 dengan signifikansi 0,000. Nilai signifikansi < taraf kesalahan 1 persen atau 0,01 sehingga dapat disimpulkan bahwa variabel status gizi $\left(\mathrm{X}_{1}\right)$, keterampilan kerja $\left(\mathrm{X}_{2}\right)$, pengalaman kerja $\left(\mathrm{X}_{3}\right)$, gaya kepemimpinan $\left(\mathrm{X}_{4}\right)$, usia $\left(X_{5}\right)$, pendidikan $\left(X_{6}\right)$ dan jenis kelamin (D) berpengaruh sangat nyata secara bersama-sama terhadap produktivitas tenaga kerja pemanenan nanas (Y) dengan tingkat kepercayaan 99 persen. Uji t atau uji parsial dilakukan untuk mengetahui apakah variabel bebas bepengaruh secara parsial terhadap variabel terikat. Hasil analisis t hitung dan siginifikansi dapat dilihat pada Tabel 5.

Berdasarkan Tabel 5 variabel status gizi memiliki nilai signifikansi sebesar 0,139 , artinya variabel ini secara parsial tidak berpengaruh terhadap produktivitas tenaga kerja pemanenan nanas, karena nilai signifikansi hasil penelitian lebih besar dari taraf kesalahan 0,10. Hasil penelitian ini berbeda dengan penelitian Simamora et all (2016) yang menyatakan status gizi berpengaruh terhadap produktivitas tenaga kerja di PTPN II karena poses pemanenannya membutuhkan tenaga ekstra. 
Tabel 5. Hasil analisis t hitung dan signifikansi dari masing-masing variabel

\begin{tabular}{lccc}
\hline \multicolumn{1}{c}{ Model } & $\mathrm{B}$ & $\mathrm{t}$ & Sig. \\
\hline (Constant) & 39,802 & 1,061 & 0,295 \\
Status Gizi & $-2,077$ & $-1,510$ & 0,139 \\
Keterampilan Kerja & 42,418 & 5,587 & $0,000^{*}$ \\
Pengalaman Kerja & 40,009 & 6,815 & $0,000^{*}$ \\
Gaya Kepemimpinan & 1,743 & 2,228 & $0,031^{*}$ \\
Mandor & 0,980 & 1,792 & $0,080^{*}$ \\
Usia & 2,776 & 1,741 & $0,089^{*}$ \\
Pendidikan & 2,873 & 0,440 & 0,662 \\
Jenis Kelamin & & & \\
Keterangan : Significant 0,100 & &
\end{tabular}

Variabel keterampilan kerja secara parsial berpengaruh terhadap produktivitas tenaga kerja pemanenan nanas di PT Great Giant Pineapple departemen PG 4 dengan tingkat kepercayaan 99 persen. Diperoleh nilai koefisien Beta variabel keterampilan kerja adalah 42,418. Nilai koefisien Beta variabel keterampilan kerja bernilai positif, artinya setiap peningkatan keterampilan tenaga kerja dapat meningkatkan produktivitas tenaga kerja pemanenan nanas. Hasil penelitian ini sejalan dengan penelitian Hamonangan et all (2015) yang menyatakan bahwa keterampilan kerja berpengaruh terhadap produktivitas kerja karyawan PT Industri Karet Nusantara Medan.

Variabel pengalaman kerja secara parsial berpengaruh terhadap produktivitas tenaga kerja pemanenan nanas dengan tingkat kepercayaan 99 persen. Diperoleh nilai koefisien Beta variabel pengalaman kerja adalah 40,009. Nilai koefisien Beta variabel pengalaman kerja bernilai positif, artinya semakin lama pengalaman kerjanya dapat meningkatkan produktivitas tenaga kerja pemanenan nanas. Hasil penelitian ini sejalan dengan penelitian Rismayadi (2015) yang menyatakan bahwa pengalaman kerja mempegaruhi produktivitas karyawan CV Mitra Bersama Lestari. Peningkatan pengalaman kerja terhadap produktivitas tenaga kerja dapat dilihat pada Gambar 2.

Berdasarkan Gambar 2, dapat diketahui bahwa semakin peningkatan pengalaman kerja berbanding lurus dengan peningkatan poduktivitas, sehingga perusahaan harus mempertimbangkan pengalaman kerja atau memberikan pelatihan intensif pada tahap awal sebelum menjadi tenaga kerja pemanenan nanas.

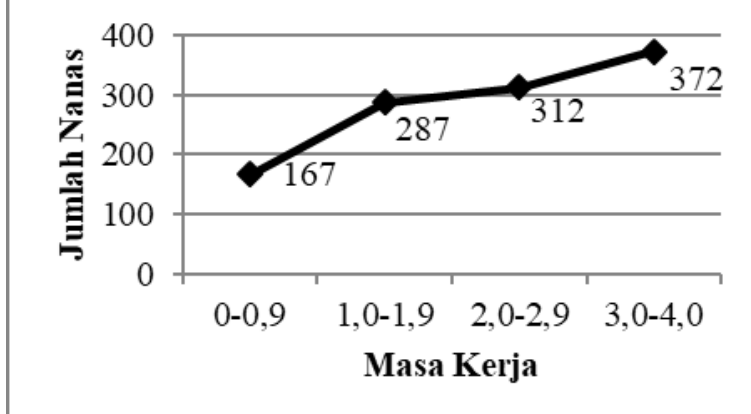

Gambar 2. Grafik peningkatan pengalaman kerja terhadap produktivitas tenaga kerja

Variabel gaya kepemimpinan mandor secara parsial berpengaruh terhadap produktivitas tenaga kerja pemanenan nanas di PT Great Giant Pineapple departemen PG 4 dengan tingkat kepercayaan 90 persen. Diperoleh nilai koeisien Beta variabel gaya kepemimpinan mandor adalah 1,743. Nilai koefisien Beta variabel gaya kepemimpinan mandor bernilai positif, artinya dengan gaya kepemimpinan mandor yang demokratis dapat meningkatkan produktivitas tenaga kerja. Hasil penelitian ini sejalan dengan penelitian Alimah et all (2016) yang menyatakan bahwa gaya kepemimpinan mandor berpengaruh terhadap kinerja pemanen PTPN VII UKKS Rejosari.

Variabel usia secara parsial berpengaruh terhadap produktivitas tenaga kerja pemanenan nanas di PT Great Giant Pineapple departemen PG 4 dengan tingkat kepercayaan 90 persen. Diperoleh nilai koefisien Beta variabel usia adalah 0,980. Nilai koefisien Beta variabel usia bernilai positif, artinya semakin tinggi usia maka semakin tinggi produktivitas tenaga kerja pemanenan nanas di PT Great Giant Pineapple departemen PG 4. Hasil penelitian ini sejalan dengan penelitian Apriliyanti (2017) yang menyatakan usia berpengaruh terhadap produktivitas tenaga kerja PT OASIS Water International Cabang Palembang.

Variabel pendidikan secara parsial berpengaruh terhadap produktivitas tenaga kerja pemanenan nanas di PT Great Giant Pineapple departemen PG 4 pada tingkat kepercayaan 90 persen. Diperoleh nilai koefisien Beta variabel pendidikan adalah 2,776. Nilai koeisien Beta variabel pendidikan bernilai positif, artinya semakin tinggi tingkat pendidikan maka semakin tinggi produktivitas tenaga kerja pemanenan nanas di PT Great Giant Pineapple departemen PG 4. Hasil penelitian ini sejalan dengan penelitian Ukkas (2017) yang menyatakan bahwa pendidikan berpengaruh terhadap produktivitas tenaga kerja 
produksi PT Mazuvo Indo. Variabel jenis kelamin memiliki nilai signifikansi sebesar 0,666 , artinya variabel ini secara parsial tidak berpengaruh terhadap produktivitas tenaga kerja pemanenan nanas di PT Great Giant Pineapple departemen PG 4, karena nilai signifikansi hasil penelitian lebih besar dari taraf kesalahan 0,10. Hal tersebut dapat terjadi karena pekerjanaan pemanenan nanas dapat dilakukan dengan sama baiknya oleh lakilaki maupun perempuan. Hasil penelitian ini berbeda dengan penelitian Ukkas (2017) yang menyatakan bahwa jenis kelamin berpengaruh terhadap produktivitas tenaga kerja industri kecil di Kota Palopo, karena terdapat perbedaan antara produktivitas tenaga kerja laki-laki dan perempuan, tenaga kerja laki-laki memiliki produktivitas yang lebih tinggi dari pada tenaga kerja perempuan

\section{KESIMPULAN}

Tingkat status gizi tenaga kerja pemanen nanas di PT Great Giant Pineapple departemen PG 4 dalam kategori normal dengan IMT 18,50-22,90, sebagian besar memiliki keterampilan kerja yang baik, dan pengalaman lebih dari satu tahun. Mandor memiliki gaya kepemimpinan demokratis yang mana produktivitas tenaga kerja pemanen nanas di PT Great Giant Pineapple departemen PG 4 mencapai kategori sedang atau dapat memanen 301-400 buah per hari. Produktivitas tenaga kerja pemanen nanas di PT Great Giant Pineapple departemen PG 4 dipengaruhi oleh keterampilan kerja, pengalaman kerja, gaya kepemimpinan mandor, usia, dan pendidikan.

\section{DAFTAR PUSTAKA}

Alimah FC, Sayekti WD, dan Soelaiman A. 2016. Hubungan gaya kepemimpinan mandor panen dan motivasi kerja pemanen dengan kinerja pemanen di PT Nusantaa VII Unit Keun Kelapa Sawit Rejosari Natar Lampung Selatan. Jurnal Ilmu Ilmu Agribisnis, 4(3): 294-300.

http://jurnal.fp.unila.ac.id/index.php/JIA/articl e/view/1504. [25 Juni 2019]

Apriliyanti S. 2017. Pengaruh usia dan masa kerja teradap produktiitas kerja ( Studi kasus PT OASIS Water International Caban Palembang). Jurnal Sistem dan Manajemen Industri, 1(2): 68-72. http://ejurnal.lppmunsera.org/index.php/JSMI/article/ view/413/pdf. [15 Januari 2019].

Badan Pusat Statistik. 2020. Istilah. Badan Pusat Statistik. Jakarta.
Busro M. 2018. Teori-Teori Manajemen Sumber Daya Manusia. https://books.google.co.id/. Prenadamedia Group. Jakarta.

Direktorat Jendral Pekebunan RI. 2013. Peran Pekebunan Dalam Perekonomian Nasional. http://ditjenbun.pertanian.go.id/. [20 Januari 2019].

Hanoman AZ, Lubis, dan Rahman A. 2015. Pengaruh keterampilan, upah, motivasi dan lingkungan keja terhadap produktivitas kerja karryawan di PT Industi Karet Nusantara Medan. Agrica. 8(1): 33-41. https://ojs.uma.ac.id/index.php/agrica/article/v iew/1058. [5 Mei 2019]

Mazdayani, Sayekti WD, dan Nugraha A. 2014. Pengaruh pengetahuan, keterampilan, motivasi dan kompensasi terhadap kinerja mandor sadap di PTPN VII. Jurnal Ilmu Ilmu

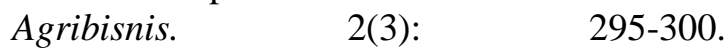
http://jurnal.fp.unila.ac.id/index.php/JIIA /article/view/813/743. [24 Juli 2020]

Rismayadi B. 2015. Faktor-faktor yang memengaruhi produktiviyas karyawan ( Studi Kasus pada CV Mitra Bersama Lestari). Jurnal Manajemen dan Bisnis. 1(1): 1-16. https://journal.ubpkarawang.ac.id. [15 Januari 2019].

Sarwono J. 2013. Mengubah Data Ordinal Ke Data Interval Dengan Metode Suksesif Interval. Www.jonathansarwono.info [09 Agustus 2019].

Simamora AWF, Sayekti WD, dan Situmorang S. 2016. Produktivitas tenaga kerja pemanen di PT Perkebunan Nusantara Vii Unit Kebun Kelapa Sawit Rejosari. Jurnal Ilmu Ilmu Agribisnis. $\quad 4(2)$ : $152-160$. http://jurnal.fp.unila.ac.id/index.php/JIA/articl e/view/1232/1129. [18 Desember 2018].

Sugiarto, Siagian D, Sunarto LS, Sunarto, Oetomo DS. 2003. Teknik sampling. Gramedia Pustaka Utama, Jakarta.s

Sugiyono. 2013. Statistik Untuk Penelitian. Alfabeta. Bandung.

Sulistiyani AT dan Rosidah. 2009. Manajemen Sumer Daya Manusia. Graha Ilmu. Yogyakarta.

Sutarto. 2006. Dasar-Dasar Organisasi. Gadjah Mada University Press. Yogyakarta.

Ukkas I. 2017. Faktor-faktor yang memengaruhi prouktivitas tenaga kerja industri kecil Kota Palopo. Journal of Islamic Education Managment. $\quad 2(2)$ : 187-198. https://ejournal.iainpalopo.ac.id/index.php/kel ola/article/440. [14 Januari 2019]. 